\title{
POTENSI ENERGI LISTRIK YANG DIHASILKAN DARI EMISI GAS METANA DI TPA SUWUNG PROVINSI BALI
}

\author{
Putu Dian Paramitha Dewi ${ }^{\left.1^{*}\right)}$, I Wayan Suarna ${ }^{2)}$, I Wayan Budiarsa Suyasa ${ }^{3)}$ \\ 1)Program Studi Magister Ilmu Lingkungan, Program Pascasarjana, Universitas Udayana \\ ${ }^{2}$ Fakultas Peternakan, Universitas Udayana \\ ${ }^{3)}$ Fakultas MIPA, Universitas Udayana \\ *Email : miss.dianparamitha@gmail.com
}

\section{ABSTRACT \\ THE POTENTIAL OF ELECTRICAL ENERGY RESULTED FROM METHANE GAS EMISSION IN SUWUNG LANDFILLS, BALI PROVINCE}

\begin{abstract}
Waste is one source of greenhouse gas emissions (GHG) that has methane gas form which caused an early multi-dimensional, massive and complex problems. The rapid increase of garbage volume entering landfill, annually resulta high garbage dumps in the Suwung Landfill area. It should have been considered a handing solution for example by converting the methane gas content in the waste into a useful value added product. The objective of this research is determining the amount of electrical energy that can be produced through methane gas emission at SuwungLandfill. The characteristic and composition of waste could give effect to the formation of methane emissions. The research on the composition and characteristic of waste were done by sorting $1 \mathrm{~m}^{3}$ of garbage sample from new garbage entering landfill. Garbage is divided based on the source of DLHK waste, market waste, and private waste. The volume of waste that went to Suwung Landfill in 2016 calculated $1.296 .438 \mathrm{~m}^{3}$ which was dominated by organic waste $(78,1 \%)$. The density of the waste that went into SuwungLandfill, based on the research's results, amounted to $135,09 \mathrm{~kg} / \mathrm{m}^{3}$, there fore could be assumed that the weight of waste that went to SuwungLandfill in 2016 was 175.135,81 tons. Based on these data, the number of $136.785,13$ tons of waste, which was organic waste, could increase the concentration of greenhouse gases in the atmosphere if this situation does not manage properly. Gravimeter method is using for measures the dry matter content value of waste. From the measurement, the results obtained the waste components that have the highest dry matter content is from rubber and leather garbage $(76,52 \%)$ while the lowest dry matter is food waste $(19,13 \%)$. By using calculations based on IPCC 2006 , it was found that the amount of methane emissions could be generated by the waste at the SuwungLandfill in 2016 , amounted to $3.535,06$ tons. Based on the energy equivalence table, the electrical power that is generated from the potential methane emissions at the Suwung Landfill is 6,66 MW.
\end{abstract}

Keywords: waste composition, waste characteristics, methane emissions, ipcc2006, electrical power

\section{PENDAHULUAN}

Berbagai aktivitas manusia memberikan dampak pada peningkatan emisi gas rumah kaca (GRK) yang sangat tinggi ke atmosfer sehingga menyebabkan timbulnya masalah pemanasan global dan perubahan iklim. Sampah merupakan salah satu penghasil emisi metana yang termasuk dalam gasrumah kaca.Permasalahan persampahan saat ini bukan lagi sebuah masalah sederhana dan berdiri sendiri, namun telah menjadi sebuah masalah yang bersifat multi dimensi, masif, serta kompleks. Metode pengolahan sampah yang ada saat ini belum optimal dalam meredam laju timbulan sampah sehingga menyebabkan volume sampah terus mengalami peningkatan yang tajam.

Dalam menghitung besarnya potensi emisi gas metana dari sampah padat, karakteristik sampah berupa komposisi dan kandungan bahan kering sampahorganik yang dapat terurai menjadi hal yang sangat penting untuk diketahui (KLH,2012).Belum adanya data karakteristik sampah yang representatif dan update untuk dapat digunakan sebagai referensi dalam perhitungan estimasi emisi GRK di Bali merupakan salah satu faktor dilakukannya studi ini.Karakteristik sampah dapat memberikan informasi mengenai banyaknya komponen sampah penghasil emisi metana, yaitu dari studi komposisi dan kandungan bahan kering sampah (fraksi Degradable Organic Carbon) (KLH, 2012).

TPA Suwung merupakan TPA terbesar di Provinsi Bali yang hingga saat ini masih menerapkan sistem open dumping dalam pengoperasiannya. Hal ini mengakibatkan terjadinya penumpukan sampah dan berpotensi memicu ledakan penyebab kebakaran akibat tingginya konsentrasi gas metana di TPA Suwung.Perlu suatu solusi untuk menangani tumpukkan sampah di TPA Suwung misal dengan menjadikan kandungan gas metana dalam sampah memiliki nilai tambah yang bermanfaat. Salah satu 
cara pemanfaatan gas metana yang berasal dari sampah adalah untuk penyediaan energi, yaitu sebagai bahan bakar penggerak mesin pembangkit listrik. Berdasarkan penelitian, pembangunan PLTSa (Pembangkit Listrik Tenaga sampah) di TPA Banda Aceh dianggap layak dengan memaparkan bahwa jumlah sampah yang masuk sebanyak 54.763,13 ton dapat menghasilkan listrik sebesar 1,7 MW dan telah sesuai dengan kriteria kelayakan proyek NPV > 0 (Ikhsan dkk., 2014). Sedangkan penelitian potensi energi listrik di TPA Cilowong dengan komposisi sampah organik sebesar 70,99\% dan jumlah sampah yang masuk setiap harinya sebanyak 120 ton/hari dapat menghasilkan listrik sebesar 2,19 MW dengan menggunakan teknologi berbasis konversi thermokimia dan sebesar1,09 MW apabila menggunakan konversi biokimia (Faridha dkk, 2015). Sampah yang masuk ke TPA Suwung di tahun 2016 memiliki jumlah yang lebih banyak dari TPA Banda Aceh maupun TPA Cilowong yakni sebesar 1.296.438 $\mathrm{m}^{3}$. Berdasarkan banyaknya jumlah sampah yang masuk, bila dibandingkan dari hasil penelitian yang telah dilakukan di kedua TPA tersebut maka potensi untuk pembangunan PLTSa di TPA Suwung sangat besar. Berdasarkan hal tersebut, maka perlu dilakukan penelitian tentang potensi energi listrik yang dapat dihasilkan dari emisi gas metana di TPA Suwung Provinsi Bali.

\section{METODOLOGI}

\subsection{Waktu dan Tempat Penelitian}

Proses pengambilan sample penelitian dan penentuan komposisi sampah dilakukan di area pembuangan sampah baru yang ada di TPA Suwung Provinsi Bali. Waktu pengambilan sample komposisi sampah dilakukan selama 30 hari berturut-turut, sedangkan waktu pengambilan sample untuk pengukuran kandungan bahan kering sampah dilakukan selama 8 hari berturut-turut.

\subsection{Sumber Data} dari :

Data yang digunakan dalam penelitian ini terdiri

a. Data primer, yaitu berupa presentase masingmasing komponen sampah (berdasarkan 3 sumber penghasil sampah yaitu Dinas Lingkungan Hidup dan Kebersihan, Perusahaan Daerah Pasar, dan Swakelola/Swasta) yang masuk ke TPA Suwung, nilai dry matter content dari masing-masing komponen sampah, dan fraksi DOC sampah.

b. Data sekunder, berupa data sumber sampah dan data volume sampah per hari yang masuk ke TPA Suwung dimasa sebelum dilakukan penelitian yang dapat diperoleh dari UPT Sampah Provinsi Bali/DLHK Kota Denpasar.

\subsection{Metode Pengambilan Sample}

\subsubsection{Sample komposisi dan karakteristik sampah}

Metode yang digunakan untuk proses pengambilan sampel komposisi sampah, karakteristik sampah, pengukuran berat kering sampah dan perhitungan besarnya emisi metana adalah SNI 19-3694-1994 (Metode Pengambilan dan Pengukuran Contoh Timbulan dan Komposisi Sampah Perkotaan) dan metode IPCC2006 Guidelines.

Metode pelaksanaan penentuan komposisi sampah dilakukan dengan mengambil sampel sampah yang baru masuk di TPA Suwung sebanyak $1 \mathrm{~m}^{3}$ (tanpa reduksi volume sampel) yang dianggap mewakili komposisi sampah yang ditimbun di TPA. Metode ini merujuk pada SNI 19-3694-1994 (Metode Pengambilan dan Pengukuran Contoh Timbulan dan Komposisi Sampah Perkotaan), namun untuk pembagian komponen sampah didasarkan pada IPCC 2006 yang membagi sampah menjadi 11 komponen (sampah makanan, sampah kebundan taman,kayu, kertas dan karton, tekstil, nappies, karet dan kulit, plastik, logam, gelas/keramik, dan lain-lain).

Persen berat masing-masing komponen dihitung dari berat sampah dan berat total (KLH, 2012).

$\%$ berat tiap komponen $=($ berat sampah masing masing komponen : berat total sampah saat sampling) x $100 \%$

Frekuensi sampling komposisi sampah akan dilakukan adalah selama 30 hari berturut-turut dilahan landfill, yaitu di tempat dimana truk menumpahkan sampah yang baru masuk.

\subsubsection{Sample pengukuran berat kering sampah}

Sample yang akan dibawa ke laboratorium untuk pengukuran berat kering diambil dari sampel yang digunakan untuk menetukan komposisi sampah dengan menggunakan metode quartering. Penentuan kandungan bahan kering hanya diterapkan untuk komponen-komponen sampah sisa makanan, kayu, kebun, kertas/karton, nappies, kain /produk tekstile, dan karet/ kulit.

Kandungan bahan kering suatu komponen sampah ditentukan dengan pendekatan gravimetry, yaitu melalui penimbangan berat suatu sampel yang representatif.

Kandungan bahan kering (dry matter content) dalam suatu komponen sampah dihitung dengan persamaan:

kandungan bahan kering $=(100 \%-\%$ kandungan

air) 


\subsection{Metode Perhitungan Emisi Metana}

\subsubsection{Menghitung nilai DOC}

Perhitungan nilai DOC dilakukan dengan persamaan berikut:

$\mathrm{DOC}_{\mathrm{i}}$ basis berat basah $=\mathrm{DOC}_{\mathrm{i}}$ basis berat kering $\mathrm{x}$ kandungan bahan kering komponen I

DOC $\quad={ }^{*}{ }_{\mathrm{i}}\left(\mathrm{DOC}_{\mathrm{i}} * \mathrm{~W}_{\mathrm{i}}\right)$

Dimana :

DOC = Fraksi degradable organic carbon pada sampah Bulk, Gram C / Gram sampah

DOCi = Fraksi degradable organic carbon pada komponensampah i (basis berat basah)

$\mathrm{Wi}=$ Fraksi komponen sampah jenis i (basis berat basah)

i = Komponen sampah (misal sampah makanan, kertas, kayu, plastik, dan lain - lain)

\subsubsection{Menghitung DDOCm dan Lo}

$\mathrm{DDOCm}=\mathrm{W} \times \mathrm{DOC} \times \mathrm{DOCf} \times \mathrm{MCf}$

Lo

$$
=\mathrm{DDOCm} \times \mathrm{F} \times \frac{16}{12}
$$

Dimana :

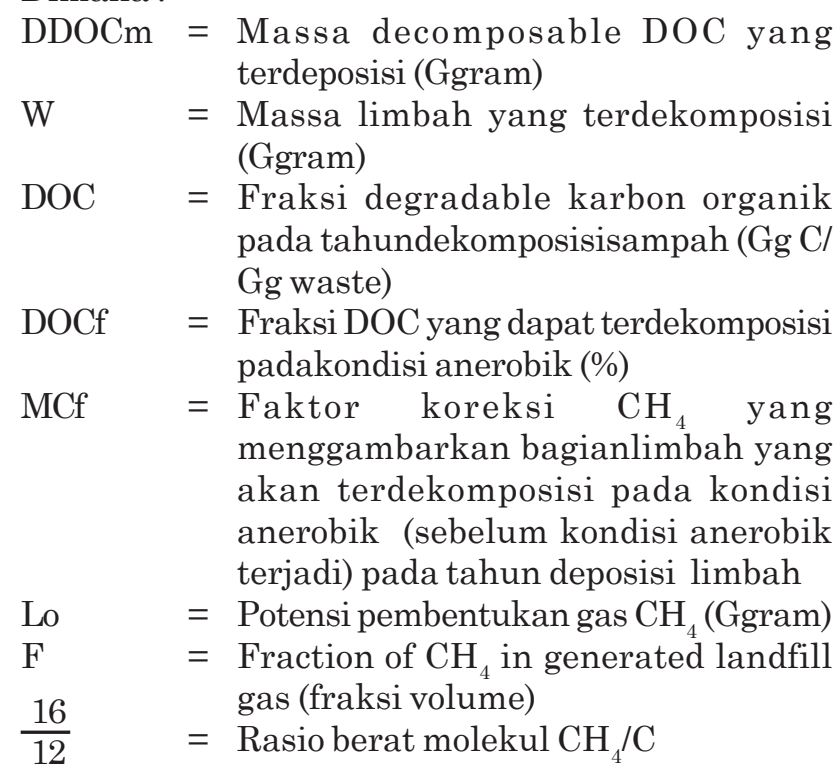

\subsection{Metode Konversi Emisi Metana Ke Energy Listrik}

Dalam proses konversi emisi gas metana menjadi energi listrik, potensi energi kalor per 1 kggas metana adalah sekitar $6,13 \times 10^{7} \mathrm{~J}$ dan $1 \mathrm{kWh}$ setara dengan $3,6 \times 10^{6} \mathrm{~J}$. Sehingga dapat diasumsikan bahwa per $1 \mathrm{~kg}$ gas metana dapat menghasilkan energy listrik sebesar $17,0278 \mathrm{kWh}$ (Sorensen, 2007). Setelah mendapatkan besarnya nilai energy listrik dalam $\mathrm{kWh}$, selanjutnya adalah menkonversi nilai tersebut kedalam satuan Watt.

Potensi daya listrik $=\mathrm{X}(\mathrm{kWh}): 8760$ jam

yang dihasilkan (W)

\section{HASIL DAN PEMBAHASAN}

\subsection{Komposisi Sampah di TPA Suwung}

Dalam penelitian ini, kendaraan pengangkut sampah yang masuk dibagi menjadi 3 (tiga) sesuai dengan sumber sampahnya yaitu kendaraan milik Dinas LHK, truk sampah PD Pasar, dan truk sampah milik swasta/swakelola. Rerata jumlah kendaraan yang masuk ke TPA Suwung adalah sebanyak 486 kendaraan per hari. Terbatasnya waktu untuk mengumpulkan sample sampah dari tiap-tiap sumber mengakibatkan jumlah kendaraan yang dijadikan sample hanya $10 \%$ dari setiap sumber sampah (Gay\&Diehl, 1992). Jumlah kendaraan dan jumlah sample secara lebih detail dapat dilihat pada tabel1.

Tabel 1. Jumlah Kendaraan Masuk ke TPA Suwung dan Jumlah Sampel Penelitian

\begin{tabular}{cccc}
\hline No & Sumber Sampah & Jumlah Kendaraan & Jumlah Sampel \\
\hline & & & ......unit....... \\
1 & DKLH & 304 & 30 \\
2 & PD Pasar & 23 & 2 \\
3 & Swakelola / swasta & 159 & 16 \\
\hline & Total & 486 & 48 \\
\hline
\end{tabular}

Sumber : DLHK Kota Denpasar (2017)

Volume sampah yang masuk ke TPA Suwung berdasarkan data yang diperoleh melalui DLHK Kota Denpasar adalah sebesar $1.296 .438 \mathrm{~m}^{3}$ sehingga dapat dihitung rata-rata volume sampah yang masuk ke TPA Suwung adalah sebesar 3.551,88 $\mathrm{m} 3 /$ hari yang berasal dari wilayah Kota Denpasar dan sebagian Kabupaten Badung. Hasil penelitian pengambilan sample sampah untuk menentukan komposisi dan karakteristik sampah di TPA Suwung dilaksanakan selama 30 hari (09 Januari - 07 Februari 2017).

Komposisi sampah yang paling dominan dari ketiga sumber sampah yang masuk ke TPA Suwung tersebut adalah adalah dari jenis sampah kebun/ taman dengan presentase sebesar $45,71 \%$. Bila dibandingkan dengan pelaksanaan survei komposisi sampah di daerah lain, terdapat perbedaan jenis sampah yang mendominasi. Hasil pelaksanaan survei yang dilakukan di TPA Batu Layang Provinsi Kalimantan Barat didominasi oleh sampah dari sisa makanan sebesar $66,0 \%$ sedangkan untuk sampah kebun/taman ada diurutan kedua sebesar 9,5\% (Khatulistiwa, 2015). Begitu juga dengan pelaksanaan survei di Kota Kendari yang memiliki presentase tertinggi adalah sampah sisa makanan sebesar 40,9\%, sedangkan sampah kebun hanya sebesar 5,5\% (Chaerul, 2016). Hal ini dikarenakan selain sampah yang berupa sisa tanaman dan kebun, sampah sisa dari kegiatan upacara keagamaan di Bali juga 
Tabel 2 Rerata Berat Tiap Komponen Sampah dari Seluruh Sumber Sampah dan Komposisi Sampah di TPA Suwung

\begin{tabular}{|c|c|c|c|c|c|c|}
\hline No. & Komponen Sampah & DLHK & PD Pasar & Swasta / Swakelola & Rerata Keseluruhan & Komposisi Sampah \\
\hline & & & \multicolumn{2}{|c|}{$\ldots \mathrm{kg} \ldots$} & \multicolumn{2}{|c|}{..$\% \ldots$} \\
\hline 1 & Makanan & 20,69 & 32,62 & 17,57 & 23,63 & 17,71 \\
\hline 2 & Kebun \& Taman & 70,57 & 56,15 & 59,50 & 62,07 & 45,71 \\
\hline 3 & Kayu & 1,49 & 1,52 & 1,66 & 1,56 & 1,16 \\
\hline 4 & Kertas \& Karton & 9,82 & 7,22 & 12,93 & 9,99 & 7,36 \\
\hline 5 & Kain \& Tekstil & 5,89 & 2,93 & 2,42 & 3,75 & 2,75 \\
\hline 6 & Nappies & 4,10 & 0,98 & 4,37 & 3,15 & 2,31 \\
\hline 7 & Karet \& Kulit & 1,71 & 1,08 & 1,65 & 1,48 & 1,10 \\
\hline 8 & Plastik & 23,36 & 22,12 & 32,28 & 25,92 & 19,26 \\
\hline 9 & Logam & 0,84 & 0,75 & 0,61 & 0,73 & 0,54 \\
\hline 10 & Gelas & 1,62 & 1,24 & 1,85 & 1,57 & 1,15 \\
\hline \multirow[t]{2}{*}{11} & Lain-lain (abu, debu) & 1,25 & 1,28 & 1,21 & 1,25 & 0,94 \\
\hline & & & & Total berat sampah & 135,09 & 100 \\
\hline
\end{tabular}

dikategorikan dalam jenis ini. Banyaknya sampah jenis ini disebabkan karena mayoritas penduduk beragama Hindu yang setiap harinya selalu melakukan kegiatan upacara keagamaan. Untuk sampah sisa kebun/taman yang bersumber dari PD Pasar didominasi oleh sisa bunga dan sisa sarana upacara yang tidak layak lagi untuk dijual.

Jenis sampah plastik ada di urutan kedua dengan presentase rata-rata sebesar 19,26\% (tabel 2) untuk sampah yang bersumber dari DKLH dan Swakelola/swasta. Sampah plastik yang masuk ke TPA Suwung didominasi oleh jenis kantong plastik/ kresek yang masih banyak digunakan dalam kehidupan sehari-hari. Berdasarkan survei, presentase sampah plastik yang ada di TPA Batu Layang dan Kota Kendari berada diurutan ketiga yaitu sebesar 8,9\% (Khatulistiwa, 2015) dan 30,9\% (Chaerul, 2016). Sedangkan urutan kedua untuk sampah yang bersumber dari PD Pasar berasal dari jenis sampah sisa makanan. Sampah sisa makanan ini sebagian besar bersumber dari sisa sayur mayur ataupun buah-buahan yang sudah tidak layak lagi untuk dijual dan dikonsumsi.

Sampah yang masuk kategori sampah organik seperti sampah sisa makanan, sisa kebun/taman, karet, kertas, kayu, nappies, dan kain merupakan komponen terbesar yang masuk ke TPA Suwung sebesar 78,10\% dan presentase sampah anorganik sebesar 21,90\%. Sampah organik merupakan jenis sampah yang mendominasi di Indonesia, hal ini berbanding terbalik dengan negara-negara maju seperti Singapura yang memiliki komposisi sampah organik sebesar 4,6\%, Hongkong $(9,4 \%)$ dan Kota London (28\%) (Damanhuri,2010). Tingkat perekonomian suatu negara dapat mempengaruhi komposisi sampah, dimana suatu negara yang memiliki tingkat perekonomian yang tinggi cenderung menghasilkan sampah anorganik seperti bahan kaleng atau plastik (Damanhuri, 2010).

Dari hasil survei komposisi sampah di Kota Bukittinggi pada tahun 2012 didapatkan komposisi sampah organik yang jauh lebih tinggi yaitu sebesar 92\% dan sampah anorganik sebesar 8\% (Ruslinda, 2012) sedangkan hasil survei komposisi sampah di Kecamatan Banyuwangi pada tahun 2007 mendapatkan hasil komposisi sampah organik sebesar $81,30 \%$ dan anorganik sebesar 28,7\% (Maharani, 2007). Dominasi sampah yang berasal dari bahan organik di TPA Suwung secara teori sangat berpotensi untuk menghasilkan emisi metana (Purwanta, 2009). Gas metana yang tidak dikelola dengan baik dan terlepas ke udara, mampu mengakibatkan peningkatan emisi gas rumah kaca yang memicu terjadinya pemanasan global. Berikut ini adalah perbandingan komposisi sampah organik dan anorganik di TPA Suwung seperti yang terlihat pada gambar 1 .

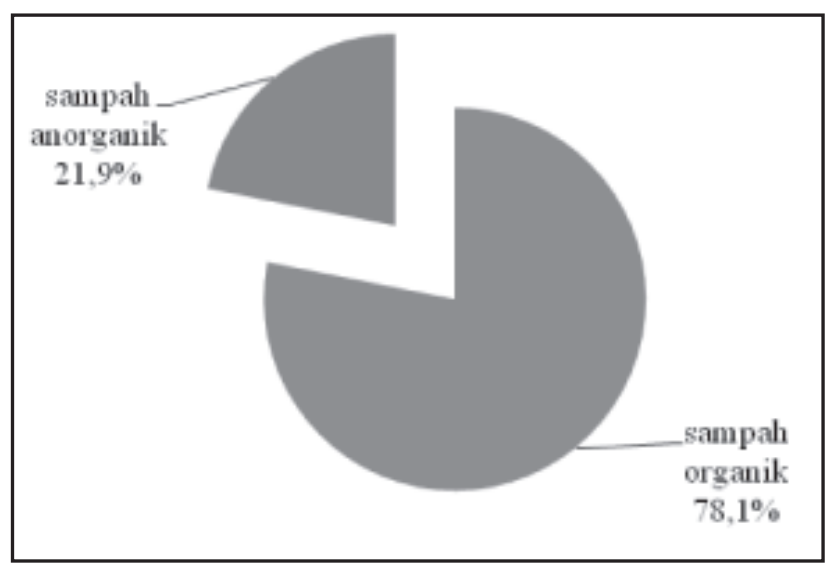

Gambar 1. Diagram Perbandingan Komposisi Sampah Organik dan Anorganik di TPA Suwung

\subsection{Karakteristik Sampah di TPA Suwung}

\subsubsection{Karakteristik Fisika}

Massa jenis/densitas adalah salah satu karakteristik fisika sampah yang merupakan berat material per unit volume $\left(\mathrm{kg} / \mathrm{m}^{3}\right)$. Komposisi sampah yang didominasi oleh sampah anorganik cenderung 
memiliki nilai densitas yang rendah karena memiliki massa yang kecil namun volume sampah tinggi/ besar, sedangkan sebaliknya untuk sampah organic memiliki volume yang kecil namun massanya cenderung besar. Perhitungan karakteristik sampah berupa massa jenis didapat dari pengukuran timbulan yaitu menggunakan data volume setelah kompaksi dan berat sampah.

Massa jenis sampah dapat dihitung dengan persamaan :

$$
\begin{aligned}
& =\frac{\mathrm{m}}{\mathrm{v}} \\
& =\frac{135.09}{1}=135.09 \mathrm{~kg} / \mathrm{m}^{3}
\end{aligned}
$$

Dimana :

$=$ densitas sampah $\left(\mathrm{kg} / \mathrm{m}^{3}\right)$

$\mathrm{m}$ = rata-rata berat sampah per hari $(\mathrm{kg})$

$\mathrm{v} \quad=$ volume $\operatorname{sampah}\left(\mathrm{m}^{3}\right)$

\subsubsection{Karakteristik kimia}

Masing-masing komponen sampah yang telah dipilah berdasarkan jenis dan sumbernya dibawa ke lab untuk pengukuran kadar air dengan metode gravimetry. Adapun sampel yang diuji di lab adalah sample yang diambil dari tanggal 09 - 16 Januari 2016 dengan cara komposit antara sample tanggal 09 dan 10 januari 2016, 11 dan 12 Januari 2016, 13 dan 14 Januari 2016, dan terakhir 15 dan 16 januari 2016.

Hasil pengukuran kandungan bahan kering sampah yang ada di TPA Suwung terdiri dari 7 komponen sampah, yaitu sampah makanan, kebun\&taman, kayu, kertas\&karton, kain\&tekstil, nappies, karet\&kulit. Pengklasifikasian komponen sampah yang diukur tersebut berdasarkan pada pendekatan metode IPCC 2006 sehingga memiliki perbedaan dengan jumlah komponen sampah pelaksanaan survei Pilot Project For Capacity Development For Developing National Green House Gas Inventories (Sub Project 3) of Capacity Development for Climate Change Strategies in Indonesia. Tabel 3 merupakan nilai rata-rata hasil pengukuran dry matter content sampah di TPA Suwung dari seluruh sumber sampah.

Tabel 3 Nilai Rerata Dry Matter Content Sampah di TPA Suwung

\begin{tabular}{lc}
\hline Komponen Sampah & Dry Matter Content \\
\hline & $\ldots \% \ldots$ \\
Makanan & 19,13 \\
Kebun \& Taman & 30,19 \\
Kayu & 71,76 \\
Kertas \& Karton & 65,63 \\
Kain \& Tekstil & 64,58 \\
Nappies & 31,76 \\
Karet \& Kulit & 76,52
\end{tabular}

Hasil uji bahan kering sampah di TPA Suwung mengalami fluktuasi setiap harinya. Rata-rata \% kadar air komponen sampah yang tertinggi adalah bersumber dari sampah sisa makanan, yang kedua adalah sampah sisa kebun/taman dan ketiga adalah nappies. Hasil ini berlaku untuk ketiga sumber sampah, baik sampah yang bersumber dari DLHK, PD Pasar, dan Swakelola/Swasta.

Survei komposisi dan kandungan bahan kering sampah di Indonesia telah dilakukan di Sumatera Utara dan Sumatera Selatan pada tahun 2011. Kegiatan ini merupakan kerjasama antara JICA (Japan International Coorporation Agency), KLHITB, BLH Sumatera Utara, dan BLH Sumatera Selatan yang merupakan bagian dari Pilot Project For Capacity Development For Developing National Green House Gas Inventories (Sub Project 3) of Capacity Development for Climate Change Strategies in Indonesia (Arjuna, 2012). Hasil survei untuk komposisi rata-rata tiap komponen sampah dari kedua provinsi tersebut digunakan sebagai acuan sementara karena saat ini belum ada country-spesific komposisi sampah yang dibuang ke TPA di Indonesia. Berdasarkan survei, hasil pengukuran dry matter content dari kedua daerah tersebut dapat dilihat pada tabel4 berikut :

\begin{tabular}{|c|c|c|}
\hline Komponen & Sumatera Utara & Sumatera Selatan \\
\hline & \multicolumn{2}{|c|}{$\ldots \% \ldots$} \\
\hline Sisa Makanan & 59 & 23 \\
\hline Kertas, karton, dan nappies & 44 & 51 \\
\hline Taman dan kayu & 57 & 50 \\
\hline Kain dan produk tekstil & 73 & 56 \\
\hline Karet dan kulit & 89 & 84 \\
\hline Plastik & 57 & 76 \\
\hline Logam & 97 & 100 \\
\hline Kaca/Gelas & 66 & 92 \\
\hline Lain-lain & 95 & 85 \\
\hline
\end{tabular}

Tabel 4. Hasil Pengukuran Dry Matter Content (Pilot Project)

Sumber : (KLH, 2012)

Dari tabel 3 dan tabel 4 dapat dibandingkan komponen sampah dari jenis sisa makanan yang ada di Sumatera Utara memiliki nilai tertinggi yaitu $59 \%$ dan terendah di TPA Suwung yaitu 19,13\%. Komponen lain yang dapat dibandingkan adalah dari jenis karet\&kulit, di TPA Suwung nilai dry matter content untuk jenis ini lebih rendah (76,52\%) dari pada di Sumater Utara (89\%) dan Sumatera Selatan (84\%).

Sulit untuk mebandingkan nilai dry matter content komponen sampah dari jenis kebun\&taman $(30,19 \%)$ serta kayu $(71,76 \%)$ yang ada di TPA Suwung dengan taman\&kayu di SumateraUtara (57\%) dan Sumatera Selatan (50\%) karena komponen tersebut dalam klasifikasi yang berbeda. Hal tersebut juga berlaku untuk komponen sampah 
kertas\&karton (di TPA Suwung 65,63\%), nappies (di TPA Suwung 31,76\%) karena dalam pengukuran yang dilakukan di Sumatera Utara (44\%) dan Sumatera Selatan (51\%) komponen sampah tersebut tergabung menjadi satu klasifikasi.

\subsection{Potensi Energi Listrik dari Emisi Metana di TPA Suwung}

Tahap awal untuk menghitung potensi energy listrik adalah dengan menghitung berat tiap komponen sampah dan kemudian DOC masingmasing komponen sampah dihitung terlebih dahulu kemudian diakumulasikan untuk semua komponen sampah. Berikut ini adalah perhitungan potensi emisi Metana dari sampah sisa makanan di TPA Suwung tahun 2016.

a. Menghitung jumlah berat sampah yang masuk ke TPA Suwung tahun 2016

Berdasarkan data yang diperoleh dari DLHK Kota Denpasar, jumlah sampah yang masuk ke TPA Suwung pada tahun 2016 adalah sebesar $1.296 .438 \mathrm{~m}^{3}$. Bila dikonversikan dalam satuan Ton, maka diperoleh berat sampah yang masuk ke TPA Suwung tahun 2016 adalah sebanyak $175.135 .809,42 \mathrm{~kg}$.

b. Estimasi berat dan presentase tiap komponen sampah di TPA Suwung

Contoh perhitungan dari sampah sisa makanan yang masuk ke TPA Suwung tahun 2016

Sisa makanan $\quad=17.71 \%$

Berat sampah makanan yang masuk ke TPA Suwung $=175.135,81$ ton $\mathrm{x} 17.71 \%$

$$
=31.022,20 \text { ton }
$$

Dengan cara yang sama, berat masing-masing komponen sampah yang masuk ke TPA Suwung tahun 2016 dapat dilihat pada tabel 5 berikut ini :

Tabel 5. Komposisi Sampah di TPA Suwung

\begin{tabular}{llrr}
\hline No. & Jenis Sampah & \multicolumn{2}{c}{ Komposisi Sampah di TPA (Ton) } \\
\hline & & $\ldots \% \ldots$ & $\ldots$ Ton... \\
1 & Makanan & 17.71 & $31,022.20$ \\
2 & Kebun \& Taman & 45.71 & $80,055.37$ \\
3 & Kayu & 1.16 & $2,032.14$ \\
4 & Kertas \& Karton & 7.36 & $12,891.51$ \\
5 & Kain \& Tekstil & 2.75 & $4,812.38$ \\
6 & Nappies & 2.31 & $4,050.16$ \\
7 & Karet \& Kulit & 1.10 & $1,921.37$ \\
8 & Plastik & 19.26 & $33,729.59$ \\
9 & Logam & 0.54 & 952.46 \\
10 & Gelas & 1.15 & $2,020.30$ \\
11 & Lain-lain (abu, debu) & 0.94 & $1,648.32$ \\
\hline \multirow{2}{*}{ Jumlah Sampah Masuk ke TPA Suwung } & $175.135,81$ \\
Tahun 2016 & & \\
\hline
\end{tabular}

c. Menghitung nilai karbon organic yang terdegradasi di tahun penimbunan (DOC) DOC $=$ Wi x \% Dry matter content x DOCi

Nilai DOC untuk sampah sisa makanan adalah sebagai berikut:

DOC $=80,87 \% \times 17.09 \% \times 38=0.05$

Perhitungan nilai DOC untuk komposisi sampah lain dapat dilihat pada tabel 6 berikut ini :

Tabel 6. Perhitungan nilai DOC sampah di TPA Suwung

\begin{tabular}{lcccc}
\hline Jenis sampah & $\begin{array}{c}\text { Fraksi Kom- } \\
\text { ponen / Wi }\end{array}$ & $\begin{array}{c}\text { Dry Matter } \\
\text { Contentt }\end{array}$ & $\begin{array}{c}\text { DOCi } \\
\text { (Dalam \% \% } \\
\text { Bahan Kering) }\end{array}$ & $\begin{array}{c}\text { Nilai } \\
\text { DOC }\end{array}$ \\
\hline Makanan & 80.87 & 19.13 & 38 & 0.06 \\
Kebun \& Taman & 69.81 & 30.19 & 49 & 0.10 \\
Kayu & 37.51 & 71.76 & 50 & 0.13 \\
Kertas \& Karton & 39.09 & 65.63 & 44 & 0.11 \\
Kain \& Tekstil & 36.71 & 64.58 & 30 & 0.07 \\
Nappies & 67.35 & 31.76 & 60 & 0.13 \\
Karet \& Kulit & 24.84 & 76.52 & 47 & 0.09 \\
& & & & 0.70 \\
\hline
\end{tabular}

Nilai DOC tiap komponen sampah berdasarkan hasil perhitungan dari sampah yang ada di TPA Suwung dan range DOC default IPCC ditunjukkan pada tabel 7 .

Tabel 7. Perbandingan Nilai DOC TPA Suwung dan DOC Default IPCC 2006

\begin{tabular}{lccc}
\hline Jenis sampah & $\begin{array}{c}\text { DOC TPA } \\
\text { Suwung }\end{array}$ & $\begin{array}{c}\text { DOC IPCC } \\
\text { 2006 }\end{array}$ & $\begin{array}{c}\text { Range DOC } \\
\text { IPCC 2006 }\end{array}$ \\
\hline Makanan & 0,06 & 0,15 & $8-20$ \\
Kebun \& Taman & 0,10 & 0,20 & $18-22$ \\
Kayu & 0,13 & 0,43 & $39-46$ \\
Kertas \& Karton & 0,11 & 0,40 & $36-45$ \\
Kain \& Tekstil & 0,07 & 0,24 & $20-40$ \\
Nappies & 0,13 & 0,24 & $18-32$ \\
Karet \& Kulit & 0,09 & 0,39 & 39 \\
\hline
\end{tabular}

d. Menghitung potensi emisi metana tahun 2016

DDOCm $=\mathrm{W} \times$ DOC $\times$ DOCf $\times$ MCf

Lo $\quad=$ DDOCm $\times$ F $\times 16 / 12$

Nilai DDOCm merupakan nilai massa DOC yang terdekomposisi, sedangkan untuk nilai DOCf dan MCF menggunakan data default dari IPCC 2006.

Nilai Lo merupakan besarnya emisi metana yang dihasilkan, sedangkan $\mathrm{F}$ merupakan fraksi metana yang dihasilkan di TPA dan 16/12 merupakan rasio dari berat molekul $\mathrm{CH} 4 / \mathrm{C}$. 
Berikut ini adalah contoh perhitungan untuk potensi emisi metana dari jenis sampah sisa makanan :

$$
\begin{aligned}
\text { DDOCm } & =31.022 \text { ton } \times 0,06 \times 0,5 \times 0,8 \\
& =729,59 \text { Ton } \\
& =729,59 \text { ton } \times 0,5 \times(16 / 12) \\
& =486,39 \text { Ton }
\end{aligned}
$$

Untuk hasil perhitungan jenis sampah lainnya, dapat dilihat pada tabel 8 berikut ini :

Tabel 8 Hasil perhitungan potensi emisi metana untuk masing-masing komponen sampah

\begin{tabular}{llrrrrr}
\hline No. & Jenis Sampah & DOCf & MCf & DDOCm & F $^{*}$ & Lo (ton) \\
\hline 1 & Makanan & 0,5 & 0,8 & 796.91 & 0,5 & 486,39 \\
2 & Kebun \& Taman & 0,5 & 0,8 & $3.603,31$ & 0,5 & $2.204,46$ \\
3 & Kayu & 0,5 & 0,8 & 68,87 & 0,5 & 72,94 \\
4 & Kertas \& Karton & 0,5 & 0,8 & 436,78 & 0,5 & 388,00 \\
5 & Kain \& Tekstil & 0,5 & 0,8 & 122,00 & 0,5 & 91,26 \\
6 & Nappies & 0,5 & 0,8 & 212,46 & 0,5 & 138,62 \\
7 & Karet \& Kulit & 0,5 & 0,8 & 62,25 & 0,5 & 45,78 \\
\hline \multicolumn{7}{c}{ Total potensi emisi metana } \\
\hline
\end{tabular}

Dari tabel 8 dapat dilihat bahwa besarnya potensi emisi metana tahun 2016 adalah sebesar $3.427,44$ Ton.

Nilai potensi tenaga listrik yang dapat dibangkitkan dari emisi metana dapat dihitung sebagai berikut:

Total potensi emisi metana $=3.427,44 \mathrm{Ton} / \mathrm{tahun}$

$1 \mathrm{~kg}$ $=3.427 .440 \mathrm{~kg} /$ tahun

$3.427 .440 \mathrm{~kg} /$ tahun

$=6,13 \times 10^{7} \mathrm{Joule}$

$=21.010 .207,2 \times 10^{7}$ joule/tahun

$1 \mathrm{kwh}$

$$
=3,6 \times 10^{6} \mathrm{~J}
$$

$21.010 .207,2 \times 10^{7}$

$=58.361 .762,83$

joule/tahun

$\mathrm{kWh} / \mathrm{tahun}$

Total potensi daya listrik yang dapat dibangkitkan adalah :

Daya listrik $(\mathrm{W})=58.361 .762,83 \mathrm{kWh} / 8760 \mathrm{jam}$

$$
=6.662,29 \mathrm{~kW}=6,66 \mathrm{MW}
$$

Dari hasil perhitungan tersebut, diperoleh potensi daya listrik yang dihasilkan dari emisi metana dengan jumlah sampah sebesar $175.135,81$ ton/tahun adalah sebesar 6,66 MW.

Dalam penelitian potensi listrik dari sampah di TPA Suwung yang dilakukan oleh Partha (2010) didapatkan besarnya energi listrik yang dapat dihasilkan dengan menggunakan teknologi gasifikasi yang memiliki efisiensi alat pembangkitan sebesar $45 \%$ dapat menghasilkan daya sebesar 6,872 MW bila nilai kalor metana tinggi dan sebesar 6,192 MW bila nilai kalor metana rendah. Sebagai perbandingan, berdasarkan hasil penelitian pembangunan PLTSa di Kota Banda Aceh dinyatakan layak untuk dilakukan dengan jumlah volume sampah per hari sebesar 150,02 tonmeskipun daya listrik yang mampu dihasilkan hanya sebesar 1,7 MW dengan efisiensi alat pembangkitan sebesar $25 \%$ (Ikhsan,2014). Di beberapa Negara lain, pemanfaatan sampah sebagai sumber energi listrik sudah banyak diterapkan. Dengan menggunakan teknologi konversi biokimia (Anaerobic Digestion), New York telah mampu menghasilkan listrik sebesar 2,3 MW dengan jumlah sampah sebanyak 187.000 ton/tahun.Di Israel telah di mulai pada tahun 2002 dengan jumlah sampah sebanyak 88.000 ton/tahun, energi listrik yang dihasilkan berkisar antara 2 -3 MW. Kota Lucknow di India pada tahun 2005 telah mampu menghasilkan energi listrik sebesar $5 \mathrm{MW}$ dengan banyak sampah seberat 165.000 ton/tahun (Farida, 2015).

\section{SIMPULAN DAN SARAN}

\subsection{Simpulan}

Berdasarkan hasil dan pembahasan penelitian, dapat diambil kesimpulan sebagai berikut :

1. Komposisi sampah yang ada di TPA Suwung didominasi oleh sampah organik sebesar 78,1\%, sedangkan komposisi sampah anorganik sebesar $21,9 \%$. Sampah dari komponen bahan organik berupa sisa kebun/taman mendominasi jenis sampah yang masuk ke TPA Suwung sebesar $45,71 \%$, sedangkan sampah sisa makan ada di urutan kedua dengan presentase sebesar 17,71\% dan komponen karet\&kulit memiliki presentase terendah sebesar 1,48\%. Jenis komponen sampah dari bahan anorganik didominasi dari sampah plastik sebesar $(19,26 \%)$ dan komponen terendah dari sampah logam $(0,54 \%)$.

2. Sampah dari komponen sisa makanan memiliki nilai kandungan bahan kering terendah $(19,13 \%)$ dan nilai kadar air yang tertinggi $(80,87 \%)$. Sampah dari komponen karet\&kulit memiliki kandungan bahan kering tertinggi $(76,52 \%)$ dan kadar air terendah (24,84\%). Sampah sisa makanan yang bersumber dari DLHK yang memiliki kadar air sebesar 78,46\% dan nilai kandungan bahan kering sebesar (21,54\%), sampah sisa makanan dari PD Pasar memiliki kadar air sebesar 81,23\% dan nilai bahan kering sebesar $18,77 \%$, sampah sisa makanan dari swakelola/swasta memiliki kadar air sebesar $82,91 \%$ dan nilai bahan kering sebesar 17,09\%. Dengan tingginya kandungan air dari sampah organic yang masuk ke TPA Suwung, maka potensi emisi metana dari sampah tersebut akan semakin besar.

3. Besarnya energi listrik yang dapat dibangkitkan dari emisi metana di TPA Suwung adalah sebesar 6,66 MW. 


\subsection{Saran}

Dari catatan-catatan selama melakukan penelitian ini, dapat diberikan saran sebagai berikut :

1. Perlu dilakukan pengambilan sampel sampah selama 2 musim yang berbeda agar dapat membandingkan hasil pengukuran kadar air dan berat kering sampah saat musim hujan dan musim kemarau, karena kadar air dalam sampah dapat mempengaruhi laju reaksi hidrolisis yang mengurai senyawa organik kompleks menjadi senyawa sederhana yang dikonsumsi oleh mikroorganisme penghasil metana.

2. Perlu dilakukan analisa dari segi ekonomis untuk mengetahui kelayakan investasi pembangunan pembangkit listrik tenaga sampah.

\section{DAFTAR PUSTAKA}

Arjuna, Jaya. 2012. Laporan Akhir Survey Komposisi dan Kandungan Bahan Kering Sampah Di Sumatera Utara(Tpa Namo BintangMedan Dan Tpa Kwala Bingai-Stabat). The Pilot Project In North Sumatra In 2011 Of Project For Capacity Development For Developing National Green House Gas Inventories (Sub Project 3) Of Project Of Capacity Development For Climate Change Strategies In Indonesia. Medan

Damanhuri, dkk. 2010. Diktat Kuliah Pengelolaan Sampah. Penerbit TL - ITB Bandung.

Eggleston S., L. Buendia , M. Kyoko, T. Ngara. 2006. 2006 IPCC Guidelines for National Greenhouse Gas Inventories. Vol 5 Waste, IGES

Farida, dkk. 2015. Potensi Pemanfaatan Sampah Menjadi Listrik Di TPA Cilowong Kota Serang Provinsi Banten. Jurnal Ketenagalistrikan dan Energi Terbarukan Vol.14 No.2 Desember 2015 : 103-116. ISSN 1978-2365.
Gay, L.R. dan Diehl, P.L. 1992. Research Methods for Business and Management. MacMillan Publishing Company. New York.

Ikhsan, dkk. 2014. Studi Kelayakan Pembangunan Pembangkit Listrik Tenaga Sampah (PLTSa) di TPA Kota Banda Aceh. Seminar Nasional dan Expo Teknik Elektro 2014. ISSN : 20088-9984. Aceh : Universitas Syiah Kuala

Khatulistiwa, dkk. 2015. Inventarisasi Emisi $\mathrm{CH}_{4}$ Di TPA Batu Layang Kota Pontianak Provinsi Kalimantan Barat. Pontianak : Fakultas Teknik Universitas Tanjungpura

KLH. 2012. Pedoman Penyelenggaraan Inventarisasi Gas Rumah Kaca Nasional Buku II Volume 4 Metodologi Perhitungan Tingkat Emisi Gas Rumah Kaca Pengelolaan Limbah. Jakarta : Kementerian Lingkungan Hidup.

Maharani, dkk. 2007. Karakteristik Sampah Dan Persepsi Masyarakat Terhadap Pengelolaan Sampah Di Kecamatan Banyuwangi Kabupaten Banyuwangi Provinsi Jawa Timur. Jurnal Ecotrophic Volume 2 No. 1 Mei 2007.

Partha, Cok Gde Indra. 2010. Penggunaan Sampah Organik Sebagai Pembangkit Listrik di TPA Suwung- Denpasar. Jurnal Majalah Ilmiah Teknologi Elektro Vol.9 No. 2 Juli-Desember 2010.

Purwanta, Wahyu. 2009. Perhitungan Emisi Gas Rumah Kaca dari Sektor Sampah Perkotaan di Indonesia. Jurnal Teknik Lingkungan Vol. 10 No. 1 : 1-8. ISSN 1441-318X.

Ruslinda,dkk. 2012. Studi Timbulan, Komposisi, dan Karakteristik Sampah Domestik Kota Bukittinggi. Jurnal Teknik Lingkungan UNAND 9 (1) : 1-12 (Januari 2012).

Sorensen, Bent. 2007. Renewable Energy: Conversion, Transmission and Storage. Oxford. Elsevier Inc. 